\title{
PENGGUNAAN MEDIA DIORAMA: SOLUSI PEMBELAJARAN MATEMATIKA MATERI SKALA TERHADAP KEMAMPUAN BERPIKIR TINGKAT TINGGI JENJANG DASAR
}

\author{
Heni Aprilia ${ }^{1}$, Linda Indiyarti Putri² \\ 1,2 Universitas Wahid Hasyim, Jl. Menoreh Selatan X/22, Semarang, Indonesia \\ Email: lindaputri5@gmail.com
}

\begin{abstract}
Learning media occupies an important position in supporting the achievement of learning goals. The use of dioramas in the process of learning mathematics on a scale material can be maximized to make learning more effective. Through the use of diorama, props will provide a real experience for students as well as being able to hone high-level thinking skills. The purpose of the study was to find out how the use of diorama media as a prop in the learning of mathematics scaled materials against the high-level thinking abilities of students. The population of 20 students in class V Ml Baitul Huda Klampisan Semarang. The research method used is a descriptive quantitative method. The data collection techniques used are observations, polls, tests, and documentation. Furthermore, the research data was tested with correlation tests. The results showed that dioramas influenced students' high levels of thinking skills. This is demonstrated by the results of statistical analysis using a product-moment correlation that the use of diorama media in mathematical learning on scale material affects the high thinking ability of students.
\end{abstract}

Keywords: Higher order thinking skill, mathematics learning, media diorama

\begin{abstract}
ABSTRAK
Media pembelajaran menempati posisi penting dalam menunjang tercapainya tujuan pembelajaran. Penggunaan alat peraga diorama dalam proses belajar matematika pada materi skala dapat dimaksimalkan agar pembelajaran menjadi lebih efektif. Melalui penggunaan alat peraga diorama akan memberikan pengalaman nyata bagi peserta didik serta mampu mengasah kemampuan berpikir tingkat tinggi. Tujuan penelitian untuk mengetahui bagaimana pengaruh penggunaan media diorama sebagai alat peraga dalam pembelajaran matematika materi skala terhadap kemampuan berpikir tingkat tinggi peserta didik. Jumlah populasi sebanyak 20 orang peserta didik kelas V MI Baitul Huda Klampisan Semarang. Metode penelitian yang digunakan adalah metode kuantitatif deskriptif. Teknik pengumpulan data yang digunakan adalah observasi, angket, tes dan dokumentasi. Selanjutnya data penelitian diuji dengan uji korelasi. Hasil penelitian menunjukkan bahwa media diorama cukup mempengaruhi kemampuan berpikir tingkat tinggi peserta didik. Hal ini ditunjukkan oleh hasil analisis statistik menggunakan korelasi product moment bahwa penggunaan media diorama dalam pembelajaran matematika pada materi skala mempengaruhi kemampuan berpikir tingat tinggi peserta didik.
\end{abstract}

Kata kunci: Kemampuan berpikir tingkat tinggi, media diorama, pembelajaran matematika

Dikirim: 8 April 2020; Diterima: 25 Agustus 2020; Dipublikasikan: 30 September 2020

Cara sitasi: Aprilia, H., \& Putri, L. I. (2020). Penggunaan media diorama: solusi pembelajaran matematika materi skala terhadap kemampuan berpikir tingkat tinggi jenjang dasar. Teorema: Teori dan Riset Matematika, 5(2), 143-155. 


\section{PENDAHULUAN}

Pendidikan merupakan usaha sadar dan terencana dalam rangka mewujudkan suasana belajar dan proses pembelajaran bagi peserta didik secara aktif untuk dapat mengembangkan potensi dirinya agar memiliki kekuatan spiritual keagamaan, pengendalian diri, kepribadian, kecerdasan, akhlak mulia, serta keterampilan yang diperlukan pada dirinya dan masyarakat (Arifuddin et al., 2018). Sedangkan belajar merupakan proses sistemik yang dinamis, konstruktif, dan organik, belajar merupakan kesatuan fungsional dari berbagai komponen belajar (Sari, 2017). Belajar merupakan suatu proses perubahan tingkah laku sebagai hasil dari interaksi dengan lingkungannya dalam memenuhi kebutuhan hidupnya (Sari et al., 2018).

Oleh karena itu dalam proses pembelajaran di kelas pendidik hendaknya dapat menyajikan pembelajaran yang efektif dan efisien sesuai pola pikir peserta didik dengan menerapkan berbagai strategi belajar serta membimbing peserta didik untuk mengembangkan motivasi belajarnya (Ratnaningsih \& Nastiti, 2018). Mata pelajaran matematika akan mampu membentuk pola pikir seseorang untuk berpikir terstuktur dan logis perlu dipelajari sedini mungkin. Dengan belajar matematika, peserta didik diharapkan dapat menghubungkan dan memahami suatu hubungan antara konsep matematika yang satu dengan dengan konsep matematika yang lain untuk memecahkan masalah dalam kehidupan sehari-hari (Arifuddin et al., 2018).

Akan tetapi fakta yang terjadi adalah kemampuan pemecahan masalah matematika masih rendah, hal ini dibuktikan dari wawancara dengan guru kelas V di Ml Baitul Huda Klampisan bahwa pencapaian hasil belajar matematika dari 20 orang peserta didik hanya sebesar $53,57 \%$, kurang dari KKM (Kriterian Kelulusan Minimal) matematika yang telah ditentukan yaitu 70. Guru mengamati bahwa kesulitan dalam mempelajari materi skala dikarenakan beberapa peserta didik masih belum menguasai materi perkalian dan pembagian dengan baik. Materi perkalian dan pembagian merupakan materi terdahulu dan merupakan pendukung dalam langkah perhitungan konsep skala. Selain itu, proses belajar mengajar di kelas jarang sekali menggunakan media bantu pembelajaran seperti alat peraga atau media belajar lainnya untuk membantu proses memahamkan peserta didik.

Kurangnya pendekatan pembelajaran secara kontekstual menjadikan kendala tersendiri bagi peserta didik dalam mengkaitkan konsep matematika sekolah dengan kehidupan sehari-hari. Dengan lebih mengekplorasi pengetahuan matematika peserta didik akan pengalaman nyata mampu meningkatkan pemahaman matematik mereka pada materi aritmatika sosial, sehingga memberikan kualitas pembelajaran yang baik (Musyafa et al., 2020). Selanjutnya, pembelajaran yang mampu mengkoneksikan antara materi pelajaran di sekolah dengan konteks kehidupan sehari-hari dapat memberikan peserta didik banyak pengalaman dalam menafsirkan masalah dan mungkin pula menumbuhkan ide-ide yang bervariasi dalam menyelesaikan permasalahan (Zakiah et al., 2019).

Guru sebagai unsur terdepan dalam proses pemahaman pengetahuan di dalam kelas harus mampu mengeksplorasi potensi keterampilan yang dimiliki peserta didik. Lebih dari itu, guru sebagai fasilitator sebaiknya mampu melihat bahwa tiap peserta didik adalah individu yang unik dan tiap keunikan itu harus diikuti dengan perlakuan yang sesuai dengan variasi pengalaman, strategi, dan perangkat berdasarkan kebutuhan (Zulfiani \& Suwarna, 2020). Keterampilan berpikir tingkat tinggi atau dalam bahasa Inggris disebut sebagai higher order thinking skills (HOTS) sangat diperlukan peserta didik karena permasalahan dalam kehidupan sesungguhnya (real life problems) bersifat kompleks, tidak terstruktur, rumit, baru, dan memerlukan keterampilan berpikir yang lebih dari sekedar mengaplikasikan apa yang telah dipelajari (Riadi \& Retnawati, 2014).

Kemampuan berpikir tingkat tinggi merupakan kemampuan aktif siswa ketika menghadapi permasalahan yang tidak biasa, ketidaktentuan, pertanyaan, dan dilema. Kemampuan ini terus berkembang maju memberikan hasil yang berlaku sesuai dengan pengetahuan dan pengalaman. Kemampuan berpikir tingkat tinggi mencakup kemampuan kognitif pada ranah menganalisis (C4), mengevaluasi (C5), dan mengkreasi (C6). Menurut Lewy (Fayakun \& Joko, 2015) indikator untuk mengukur kemampuan berpikir tingkat tinggi dijelaskan dalam Tabel 1. 
Tabel 1. Indikator kemampuan berpikir tingkat tinggi

\begin{tabular}{|c|c|c|}
\hline Menganalisis (C4) & Mengevaluasi (C5) & Mengkreasi (C6) \\
\hline $\begin{array}{l}\text { Menganalisis informasi yang masuk } \\
\text { dan membagi-bagi atau } \\
\text { menstrukturkan informasi kedalam } \\
\text { bagian yang lebih kecil untuk } \\
\text { mengenali pola atau hubungannya. }\end{array}$ & $\begin{array}{l}\text { Memberikan penilaian terhadap } \\
\text { solusi, gagasan, dan metodologi } \\
\text { dengan menggunakan kriteria yang } \\
\text { cocok atau standar yang ada untuk } \\
\text { memastikan nilai efektivitas atau } \\
\text { manfaatnya. }\end{array}$ & $\begin{array}{l}\text { Membuat generalisasi suatu ide atau } \\
\text { cara pandang terhadap sesuatu. }\end{array}$ \\
\hline $\begin{array}{l}\text { Mampu mengenali serta } \\
\text { membedakan faktor penyebab dan } \\
\text { akibat dari sebuah skenario yang } \\
\text { rumit. }\end{array}$ & $\begin{array}{l}\text { Membuat hipotesis, mengkritik dan } \\
\text { melakukan pengujian. }\end{array}$ & $\begin{array}{l}\text { Merancang suatu cara untuk } \\
\text { menyelesaikan masalah }\end{array}$ \\
\hline $\begin{array}{l}\text { Mengidentifikasi atau merumuskan } \\
\text { pertanyaan }\end{array}$ & $\begin{array}{l}\text { Menerima atau menolak suatu } \\
\text { pernyataan berdasarkan kriteria yang } \\
\text { telah ditetapkan }\end{array}$ & $\begin{array}{l}\text { Mengorganisasikan unsur-unsur atau } \\
\text { bagian-bagian menjadi struktur baru } \\
\text { yang belum pernah ada sebelumnya. }\end{array}$ \\
\hline
\end{tabular}

Pembiasaan menghadirkan pemikiran analisis, menilai, dan mencipta dalam memecahkan masalah merupakan strategi dalam mencapai kemampuan berpikir tingkat tinggi (Sofiyah et al., 2015). Kemampuan analisis tingkat tinggi juga perlu diajarkan kepada peserta didik sejak dini agar mampu mengolah informasi dan membuat keputusan yang tepat dan cepat pada masa sekarang. Peserta didik perlu mengembangkan cara-cara berpikir dan bernalar secara logis berdasarkan fakta (Lestari et al., 2017). Untuk mengasah kemampuan berpikir tingkat tinggi bagi peserta didik, guru memerlukan metode ataupun media pembelajaran untuk membantu peserta didik mengembangkan kemampuan berpikir tingkat tinggi dan mengatasi masalah tersebut. Dalam hal ini siswa perlu memiliki kemampuan untuk membuat prediksi, perencanaan, pemantauan dan evaluasi pada proses penyelesaian masalah (Zakiah, 2016). Penggunaan media maupun alat peraga secara kreatif akan memungkinkan peserta didik untuk belajar lebih baik dan dapat meningkatkan performan mereka sesuai dengan tujuan yang ingin dicapai. Media pengajaran yang digunakan dapat berupa peralatan yang efektif yaitu alat peraga (Murdiyanto \& Mahatama, 2014).

Untuk mendukung penelitian ini akan ditampilkan beberapa riset terdahulu untuk mendesain kerangka penelitian bahwa dalam menciptakan pembelajaran yang kondusif dan efektif memerlukan berbagai strategi pembelajaran inovatif. Literatur pertama yang relevan hasil penelitian Nurhayati et al. (2019) menyatakan bahwa pengaruh penerapan crossword puzzle sebagai salah satu strategi pembelajaran aktif memberikan hasil yang signifikan. Populasi dalam penelitian ini adalah semua peserta didik kelas $\mathrm{V}$ yang berjumlah 21 peserta didik. Selanjutnya data hasil penelitian diuji menggunakan uji regresi. Hasil penelitian menunjukkan bahwa nilai signifikansi pada uji regresi sebesar 0,000 . Karena nilai signifikansi lebih kecil dari 0,05 dan thitung (4.316) lebih besar dari t tabel (1.72913), maka simpulan yang didapatkan adalah penerapan strategi crossword puzzle berpengaruh signifikan terhadap motivasi belajar peserta didik.

Selanjutnya Sutiarso et al. (2018) telah melakukan penelitian eksperimen semu dengan desain kelompok kontrol pretes-postes, yang bertujuan untuk menentukan pengaruh media scaffolding terhadap peningkatan pemahaman konsep geometri. Penelitian yang dilakukan di kelas 5 SDN 1 Gunung Terang Bandar Lampung dengan jumlah seluruhnya 40 peserta didik terbagi dalam 20 orang kelas kontrol dan 20 orang kelas eksperimen. Hasil penelitian menunjukkan bahwa pengaruh media scaffolding terhadap pemahaman konsep geometri peserta didik adalah cukup efektif.

Penelitian Lestari \& Mulyani (2015) juga menawarkan solusi terkait usaha meningkatkan kemampuan kognitif peserta didik dibuktikan dengan hasil uji-t diperoleh thit sebesar 2,678, jika dibandingkan dengan harga $t_{\text {tab }}$ sebesar 1,667 , maka $t_{\text {hit }}>t_{\text {tab }}(2,678>1,667)$. Sehingga terdapat perbedaan yang signifikan hasil belajar kelompok eksperimen yang menggunakan media diorama dengan kelompok kontrol yang tidak menggunakan media diorama. Dari hasil tersebut dapat disimpulkan bahwa penggunaan media diorama berpengaruh signifikan terhadap hasil belajar. 
Peserta didik MI Baitul Huda kelas V juga masih kesulitan dalam menyelesaikan soal matematika skala dalam bentuk cerita. Menurut Abidin (Susanti et al., 2020) soal cerita disajikan dalam bentuk cerita pendek dan diambil dari pemahaman cerita atau permasalahan dalam kehidupan sehari-hari peserta didik dan perlu diubah kedalam pemodelan matematika. Media Diorama dihadirkan dalam pembelajaran materi skala dengan tujuan untuk mengetahui bagaimana pengaruh penggunaan media diorama sebagai alat peraga dalam pembelajaran matematika materi skala terhadap kemampuan berpikir tingkat tinggi peserta didik kelas V MI Baitul Huda. Media diorama diharapkan membantu peserta didik dalam memahami permasalahan dalam soal cerita dengan cara menganalisis sesuai dengan taksonomi Bloom pada tingkat C4 (menganalisis).

\section{METODE PENELITIAN}

Penelitian ini menggunakan metode penelitian kuantitatif dengan analisis statistik korelasi. Selanjutnya menentukan Variabel bebas $(X)$ pada penelitian ini adalah media diorama, sedangkan variabel terikat $(Y)$ adalah kemampuan berpikir tingkat tinggi. Penelitian menggunakan design one-short case study dimana paradigma ini dapat dilihat pada Gambar 1.

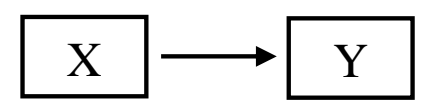

Gambar 1. Bagan kerangka pikir penelitian korelasi $X$ terhadap $Y$

Penelitian ini dilakukan di MI Baitul Huda dengan populasi seluruh peserta didik kelas $\mathrm{V}$ yang berjumlah 20 peserta didik. Sementara itu, untuk menentukan jumlah sampel, peneliti mengacu dari ketentuan yang dikemukakan Arikunto (2006) yaitu untuk sekedar ancer-ancer maka apabila subyeknya kurang dari 100, lebih baik diambil semua, sehingga penelitiannya merupakan penelitian populasi totalitas. Selanjutnya jika subyeknya besar dapat diambil $10-15 \%$ atau $20-25 \%$. Adapun untuk menetukan sampel, peneliti menggunakan teknik sampling jenuh, yaitu peneliti mengambil semua populasi dari kelas $\mathrm{V}$ yang berjumlah 20 peserta didik untuk dijadikan sampel.

Teknik pengumpulan data primer diperoleh pertama, menggunakan instrumen angket yang terdiri atas 11 item soal pengembangan dari 6 indikator variabel penelitian media pembelajaran diorama meliputi: mengatasi kesulitan yang muncul ketika mempelajari objek yang terlalu besar, mempelajari objek yang telah menjadi sejarah di masa lampau, mempelajari objek yang tak terjangkau secara fisik, mempelajari objek yang mudah dijangkau tetapi tidak memberikan keterangan yang memadai, mempelajari konstruksikonstruksi yang abstrak, memperlihatkan proses dari objek yang luas yang disebar kepada 20 orang responden.

Kedua, tes tertulis yang terdiri dari pretest dan posttest sebanyak 20 item soal pilihan ganda yang disebar kepada 20 orang responden. Ketiga, observasi terkait proses kegiatan belajar mengajar di dalam kelas menggunakan media diorama, dan keempat adalah teknik wawancara untuk untuk menggali dan mendapatkan informasi atau data secara langsung dari responden. Sedangkan dokumentasi sebagai teknik pengumpulan sumber data sekunder diperoleh dari berbagai literatur artikel di dalam jurnal terakreditasi, foto-foto kegiatan selama penelitian, dokumen berupa arsip yang di dapat dari pihak MI Baitul Huda, serta situs dari internet yang relevan dengan penelitian ini.

Selanjutnya data hasil penelitian dianalisis menggunakan uji analisis data hasil observasi aktivitas guru dan peserta didik. Analisis data observasi digunakan untuk mendapatkan data variable $X$ yaitu penggunaan media diorama. Dalam pengolahan data penelitian ini menggunakan rumus prosentase observasi berikut ini:

$$
\begin{aligned}
& P=\frac{F}{N} \times 100 \% \text { (Sudijono, 2012) } \\
& \text { Atau } \\
& \text { Rata }- \text { rata }=\frac{\Sigma \text { perolehan nilai }}{\Sigma \text { nilai keseluruhan }} \times 100 \% \text { (Sugiyono, 2016) }
\end{aligned}
$$


Langkah awal yang dilakukan peneliti adalah tahap analisis pendahuluan dengan cara mengumpulkan data tentang proses belajar mengajar terhadap sikap peserta didik dengan memberikan angket, dengan tujuan melihat antusias peserta didik dalam penerapan media diorama terhadap kemampuan berpikir tingkat tinggi peserta didik kelas V MI Baitul Huda menggunakan angket. Adapun alternatif jawaban beserta penskoran sebagai berikut: Selalu (SL) skor 5; Sering (SR) skor 4; Kadangkadang (KD) skor 3; Jarang (JR) skor 2; Tidak Pernah (TP) skor 1.

Selanjutnya, uji hipotesis penelitian ini menggunakan korelasi product moment. Pada analisis ini bertujuan untuk mengetahui bagaimana pengaruh antar variabel dan seberapa besar pengaruh media diorama terhadap kemampuan berpikir tingkat tinggi kelas $\mathrm{V}$ mata pembelajaran matematika materi skala. Adapun korelasi yang peneliti gunakan yaitu korelasi product moment dengan rumus (Sugiyono, 2015):

$$
\begin{aligned}
& r_{x y}=\frac{N \Sigma X Y-(\Sigma X)(\Sigma Y)}{\sqrt{\left[N \Sigma X^{2}-(\Sigma X)^{2}\right]\left[N \Sigma Y^{2}-(\Sigma Y)^{2}\right]}} \\
& \text { Keterangan: } \\
& r_{x y}=\text { koefisien validasi } \\
& x \quad=\text { skor butir soal } \\
& y \quad=\text { skor total } \\
& N \quad=\text { jumlah responden } \\
& \sum x=\text { jumlah variabel } x \\
& \sum y=\text { jumlah variabel } y
\end{aligned}
$$

Setelah diketahui hasil penelitian, kemudian diinterprestasikan lebih lanjut dengan menggunakan rh dan rt, dengan taraf signifikan $5 \%$. Jika rh > rt maka hipotesis alternatif diterima sedangkan hipotesis nol ditolak artinya Ada pengaruh signifikan penggunaan media diorama terhadap kemampuan berpikir tingkat tinggi siswa kelas V pada pembelajaran matematika materi skala MI Baitul Huda. Sedangkan, jika Jika rh < it maka hipotesis nol diterima sedangkan hipotesis alternatif ditolak artinya tidak ada pengaruh signifikan media diorama terhadap kemampuan berpikir tingkat tinggi siswa kelas $\mathrm{V}$ pada pembelajaran matematika materi skala MI Baitul Huda.

Analisis berikutnya adalah uji regresi linier sederhana ini dimaksudkan untuk mengetahui seberapa besar tingkat pengaruh media diorama terhadap kemampuan berpikir tingkat tinggi siswa. Uji determinasi (R Square) bertujuan untuk mengetahui seberapa besar kemampuan variabel independen media diorama mampu menjelaskan variabel dependen (kemampuan berpikir tingkat tinggi). Selanjutnya, analisis uji t secara parsial dimaksudkan untuk mengetahui ada atau tidaknya pengaruh variabel bebas secara parsial terhadap variabel terikat.

\section{HASIL DAN PEMBAHASAN}

\section{Penggunaan Media Diorama pada Materi Skala di Kelas V MI Baitul Huda}

Jenis diorama yang digunakan dalam penelitian ini adalah diorama terbuka, dimana objek terletak di bidang datar sebagai alas dan tidak dilengkapi oleh dinding batas pandangan. Diorama merupakan pemandangan sebuah dimensi mini, bertujuan untuk menggambarkan pemandangan sebenarnya dengan menggunakan skala yang disesuaikan dengan jarak sebenarnya. Tema pada media diorama adalah icon kota Semarang dengan mengambil objek bangunan yang memiliki nilai historis dan menjadi tempat wisata di sekitar kota Semarang. Objek yang dipilih adalah Klenteng Sampokong, Tugu Muda, Gereja Blenduk, dan Masjid Agung Jawa Tengah. Diorama dapat dilihat pada Gambar 2.

Dari hasil observasi dalam proses pembelajaran menggunakan media diorama menunjukkan bahwa kelebihan antara lain mengurangi efek bosan pembelajaran di kelas, memberikan gambaran kejadian yang sebenarnya dalam bentuk kecil sehingga mempermudah dalam memahami suatu materi pembelajaran. Namun media ini tidak mampu menjangkau sasaran dalam jumlah yang besar, pembuatannya juga membutuhkan waktu lama dan biaya yang tidak sedikit, sehingga guru harus lebih bisa mengkreasikan menggunakan bahan-bahan yang mudah didapat dan harga yang lebih terjangkau. 


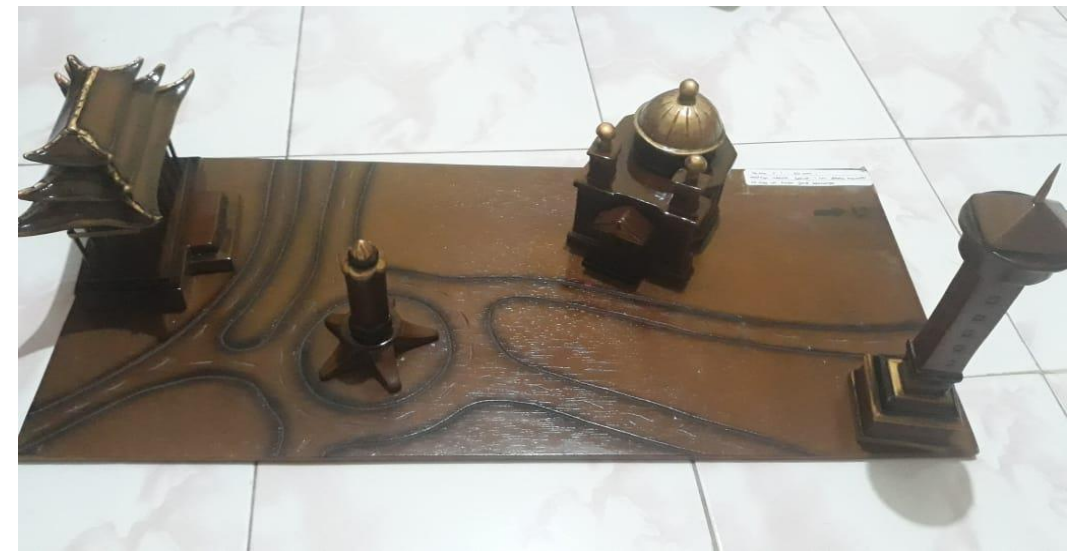

Keterangan:

$A=$ Sampokong

$\mathrm{B}=$ Tugu muda

$C=$ Gereja blenduk

$\mathrm{D}=$ Masjid agung

Skala 1: 1.000

Gambar 2. Diorama icon kota Semarang sebagai pembelajaran matematika skala

Pembelajaran matematika menggunakan media diorama di kelas V Ml Baitul Huda telah dilaksanakan dan mendapat hasil yang diharapkan. Dari hasil wawancara terhadap peserta didik dan mereka mengatakan merasa senang dan tertarik seperti yang disampaikan dari hasil wawancara berikut.

Responden 1 menyatakan bahwa:

"Kita merasa senang dan tertarik juga tidak bosen selama proses pembelajaran, soalnya cara guru menyampaikan materi dengan ada media, terus juga praktik menggunakan medianya, jadinya seru."

Responden 2 menyatakan bahwa:

"Adanya media pembelajaran sangat membantu proses pembelajaran serta dapat meningkatkan kemampuan berpikir tingkat tinggi dengan cara mempraktekan langsung bagaimana proses menyelesaikan masalah pada materi skala ini tersebut tidak hanya jadi angan-angan mereka saja"

Dilihat dari respon dinyatakan bahwa peserta didik sangat senang dan tertarik dengan digunakanya media diorama dalam pembelajaran matematika materi skala. Dalam proses pembelajaran matematika ini guru juga harus memerhatikan media yang digunakan seperti yang diungkapkan oleh guru kelas V Rafika bahwa dengan adanya media pembelajaran sangat membantu proses pembelajaran serta dapat meningkatkan kemampuan berpikir tingkat tinggi dengan cara mempraktekan langsung bagaimana proses menyelesaikan masalah pada materi skala ini tersebut tidak hanya jadi angan-angan mereka saja. Kegiatan pembelajaran menggunakan media diorama dapat dilihat pada Gambar 3.

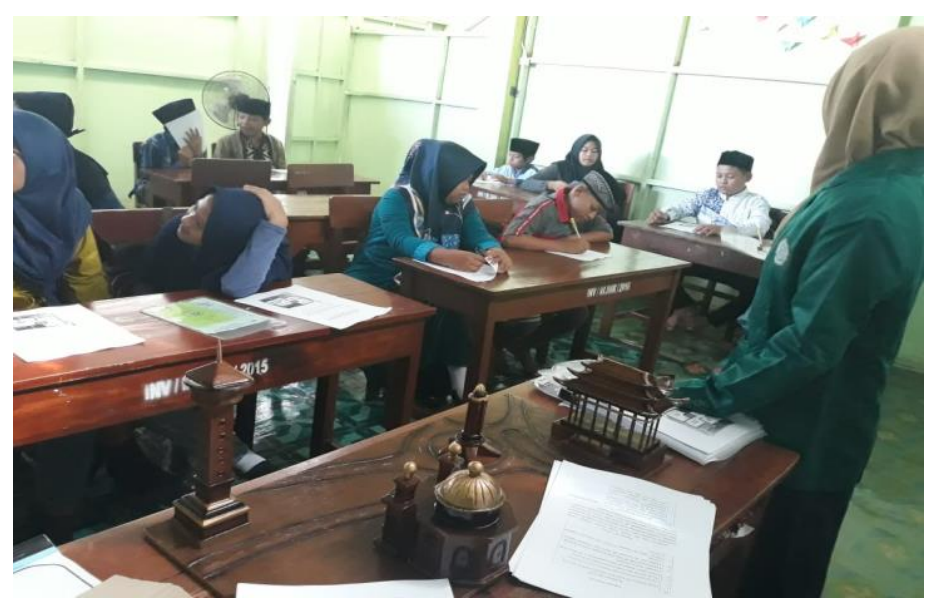

Gambar 3. Kegiatan pembelajaran matematika menggunakan media diorama 
Manfaat penting dari media diorama antara lain peserta didik dapat mengeksplorasi pengetahuannya secara lansung dan memberikan kesempatan untuk menemukan pengalaman belajar yang mandiri. Hal ini disebabkan karena selain peserta didik dapat materi dari guru juga dilatih untuk menemukan jawaban sendiri mengenai masalah yang dihadapi sehingga peserta didik dapat pengetahuan yang lebih mendalam, hal ini juga dapat peserta didik untuk berpikir tingkat tinggi dan lebih peduli dengan bangunan-bangunan sejarah di sekitar.

Angket peserta didik yang terdiri dari 11 item pertanyaan yang telah di distribusikan kepada 20 responden. Hal ini bertujuan untuk mengetahui respon peserta didik terhadap penggunaan media diorama sebagai alat peraga dalam pembelajaran matematika materi skala. Indikator pada variabel penggunaan media pembelajaran diorama meliputi, mengatasi kesulitan yang muncul ketika mempelajari objek yang terlalu besar, mempelajari objek yang telah menjadi sejarah di masa lampau, mempelajari objek yang tak terjangkau secara fisik, mempelajari objek yang mudah dijangkau tetapi tidak memberikan keterangan yang memadai, mempelajari konstruksi-konstruksi yang abstrak, memperlihatkan proses dari objek yang luas. Berikut sajian perolehan data kuantitatif respon peserta didik dapat dilihat pada Gambar 4 .

\section{Diagram Hasil Angket Responden Peserta Didik Penggunaan Media Diorama}

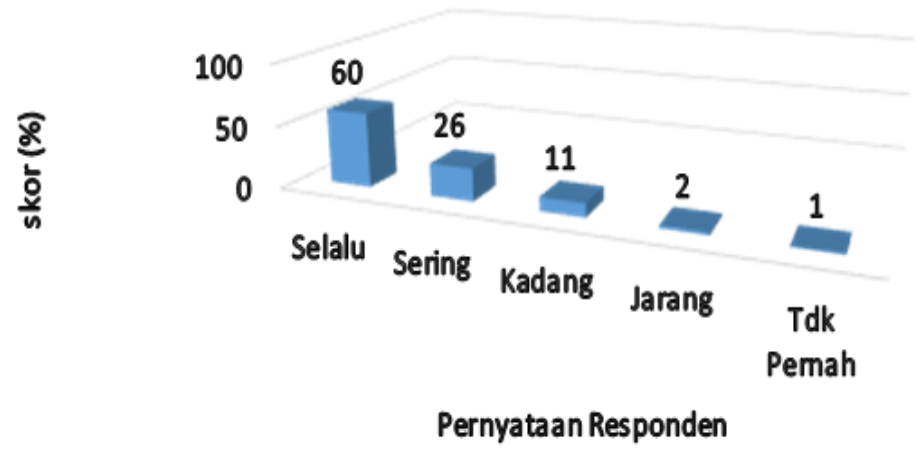

Gambar 4. Diagram hasil rekapitulasi angket

Dari Gambar 4 menunjukkan media diorama di kelas V MI Baitul Huda Klampisan Ngaliyan Semarang 2018/2019 menyatakan dengan kategori yang baik. Hal ini dapat dilihat dari jawaban responden yang menyatakan atas pilihan jawaban yang rata- rata memilih SL (selalu) sebanyak $60 \%$, SR (sering) sebanyak 26\%, KD (kadang-kadang) sebanyak 11\%, JR ( jarang) sebanyak 2\%, dan memilih jawaban TP ( tidak pernah ) sebanyak 1\%. Sementara itu, rekapitulasi angket respon peserta didik terhadap media diorama disajikan dalam Tabel 2.

Tabel 2. Rekapitulasi angket respon peserta didik terhadap media diorama

\begin{tabular}{cccc}
\hline No & $\mathbf{x}$ (skor) & Frekuensi & $\mathbf{x . f}$ \\
\hline 1 & 42 & 2 & 84 \\
2 & 44 & 2 & 88 \\
3 & 45 & 3 & 135 \\
4 & 47 & 2 & 94 \\
5 & 49 & 3 & 147 \\
6 & 50 & 3 & 150 \\
7 & 51 & 1 & 51 \\
8 & 52 & 2 & 104 \\
9 & 53 & 1 & 53 \\
10 & 54 & 1 & 54 \\
& Jumlah & 20 & 960 \\
\hline
\end{tabular}


Diperoleh hitungan rata-rata:

$$
\begin{aligned}
& \bar{x}=\frac{\sum f x}{n} \\
& \bar{x}=\frac{960}{20} \\
& \bar{x}=48
\end{aligned}
$$

Hasil perhitungan menunjukan bahwa penggunaan media diorama yang diterapkan di dalam kelas dikategorikan baik dibuktikan dengan nilai mean sebesar 48. Artinya pembelajaran matematika materi skala menggunakan media diorama baik diterapkan di kelas V MI Baitul Huda.

Perlu mengontrol pengaruh dari nilai variable independen terhadap variable dependen dengan melakukan serangkaian tes (pretest dan posttest) secara statistik (Creswell, 2009). Oleh karena itu, kemampuan berpikir tingkat tinggi pada pembelajaran matematika materi skala ini diperoleh dari nilai pretest dan posttest melalui pemberian lembar soal kepada peserta didik kelas V MI Baitul Huda. Hasil belajar kemampuan berpikir tingkat tinggi pada pembelajaran matematika materi skala sebelum diberikan pembelajaran menggunakan media diorama dapat dilihat dari hasil pretest. Rekapitulasi perhitungan ratarata pretest kemampuan berpikir tingkat tinggi pada pembelajaran matematika materi skala dapat dilihat pada Tabel 3.

Tabel 3. Rekapitulasi pretest kemampuan berpikir tingkat tinggi pada pembelajaran matematika materi skala

\begin{tabular}{cccc}
\hline No & $\mathbf{x}$ ( skor) & Frekuensi & X.f \\
\hline 1 & 35 & 2 & 70 \\
2 & 40 & 5 & 200 \\
3 & 45 & 1 & 45 \\
4 & 50 & 2 & 100 \\
5 & 55 & 4 & 220 \\
6 & 60 & 4 & 240 \\
7 & 65 & 2 & 130 \\
\multicolumn{2}{l}{ Jumlah } & 20 & 1005 \\
\hline
\end{tabular}

Diperoleh hitungan rata-rata:

$$
\begin{aligned}
& \bar{x}=\frac{\sum f x}{n} \\
& \bar{x}=\frac{1005}{20} \\
& \bar{x}=50,25
\end{aligned}
$$

Diperoleh hasil perhitungan pretest dengan mean 50,25 sehingga masih belum memenuhi target dari pencapaian KKM sebesar 70. Artinya bahwa kemampuan berpikir tingkat tinggi siswa kelas $\mathrm{V}$ pada pembelajaran matematika materi skala sebelum menggunakan media diorama tergolong masih kurang. Kemudian, setelah diberikan perlakuan pembelajaran materi skala menggunakan media diorama responden diberikan posttest. Hasil rekapitulasi dapat dilihat dalam Tabel 4.

Tabel 4. Rekapitulasi posttest kemampuan berpikir tingkat tinggi pada pembelajaran matematika materi skala

\begin{tabular}{cccc}
\hline No. & $\mathbf{x}$ ( skor) & Frekuensi & x.f \\
\hline 1 & 75 & 1 & 75 \\
2 & 80 & 5 & 400 \\
3 & 85 & 4 & 340 \\
4 & 90 & 1 & 90 \\
5 & 95 & 5 & 475 \\
6 & 100 & 4 & 400 \\
& Jumlah & 20 & 1780 \\
\hline
\end{tabular}


Diperoleh hitungan rata-rata:

$$
\begin{aligned}
& \bar{x}=\frac{\sum f x}{n} \\
& \bar{x}=\frac{1780}{20} \\
& \bar{x}=89
\end{aligned}
$$

Diperoleh hasil perhitungan posttest dengan mean 89 sehingga sudah memenuhi target dari pencapaian KKM sebesar 70 . Artinya bahwa kemampuan berpikir tingkat tinggi siswa kelas $\mathrm{V}$ pada pembelajaran matematika materi skala setelah menggunakan media diorama tergolong baik. Data hasil pretest dan posttest kemampuan berpikir tingkat tinggi dapat dilihat dalam Gambar 2.

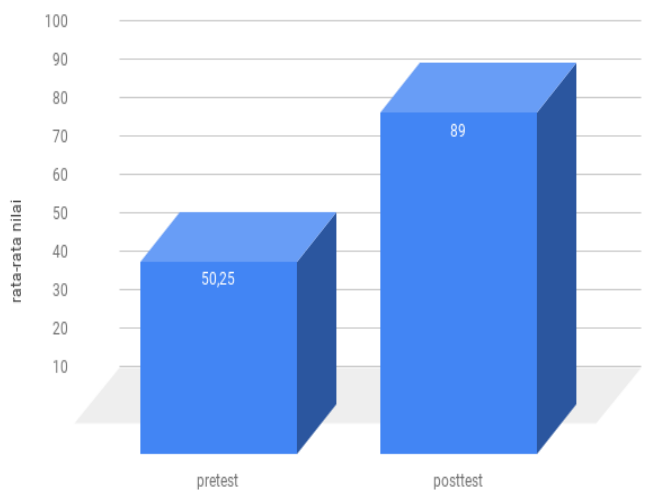

Gambar 2. Hasil perbandingan hasil pretest dan posttest

Data menyebutkan bahwa dari hasil pretest peserta didik mendapatkan nilai mean pretest yaitu sebesar 50,25. Hal ini berarti bahwa nilai pretest siswa belum mencapai ketuntasan klasikal. Tidak ada yang mencapai kriteria ketuntasan minimal. Dapat disimpulkan bahwa kemampuan berpikir tingkat tinggi siswa kelas $\mathrm{V}$ pada pembelajaran matematika materi skala sebelum menggunakan media diorama tergolong kurang. Kemudian dilanjutkan analisis hasil nilai posttest memperoleh rata-rata nilai sebesar 89 . Sebanyak 20 responden telah mencapai ketuntasan belajar. Hal ini berarti bahwa kemampuan berpikir tingkat tinggi siswa kelas $\mathrm{V}$ pada pembelajaran matematika materi skala setelah diberi perlakuan menggunakan media diorama tergolong baik.

\section{Pengaruh Media Diorama terhadap Kemampuan Berpikir Tingkat Tinggi di Kelas V MI Hidayatul Huda}

Untuk mengetahui ada tidaknya pengaruh penggunaan media diorama terhadap kemampuan berpikir tingkat tinggi matematika siswa dapat dilakukan dengan uji regresi, yang meliputi uji determinasi dan uji koefesien regresi.

1. Koefisien determinasi (R Square)

Koefisien determinasi (R Square) bertujuan untuk mengetahui seberapa besar kemampuan variabel independen media diorama mampu menjelaskan variabel dependen (kemampuan berpikir tingkat tinggi). Berikut ini hasil uji determinasi (R Square) pada Tabel 5.

Tabel 5. Hasil uji determinasi

\begin{tabular}{ccccc}
\hline \multicolumn{4}{c}{ Model Summary } \\
\hline Model & $\mathrm{R}$ & $\mathrm{R}$ Square & Adjusted R Square & $\begin{array}{c}\text { Std. Error of the } \\
\text { Estimate }\end{array}$ \\
1 & $.486^{\mathrm{a}}$ & .236 & .193 & 7.514 \\
\hline
\end{tabular}

Berdasarkan Tabel 5 , diketahui nilai koefisien determinasi atau $\mathrm{R}$ square adalah sebesar 0,236 atau sama dengan $23,6 \%$. Angka tersebut mengandung arti bahwa variable $\mathrm{X}$ berpengaruh 
terhadap variabel $Y$ sebesar $23,6 \%$. Sedangkan sisanya $76,4 \%$ dipengaruhi oleh variabel lain yang tidak diketahui dan tidak termasuk dalam analisis ini.

2. Uji Koefisien Regresi

Metode regresi linier sederhana ini dimaksudkan untuk mengetahui seberapa besar tingkat pengaruh media diorama terhadap kemampuan berpikir tingkat tinggi siswa kelas $\mathrm{V}$ pada pelajaran matematika materi skala. Hasil uji regresi linier sederhana disajikan pada Tabel 6.

Tabel 6. Hasil uji persamaan regresi linier sederhana

Coefficients $^{\mathrm{a}}$

\begin{tabular}{|c|c|c|c|c|c|c|}
\hline \multirow{2}{*}{\multicolumn{2}{|c|}{ Model }} & \multicolumn{3}{|r|}{$\begin{array}{c}\text { Standardized } \\
\text { coefficients }\end{array}$} & \multirow[b]{2}{*}{$t$} & \multirow[b]{2}{*}{ Sig. } \\
\hline & & B & Std. Error & Beta & & \\
\hline \multirow[t]{2}{*}{1} & (Constant) & 35.240 & 22.874 & & 1.541 & .141 \\
\hline & X & 1.120 & .475 & .486 & 2.357 & .030 \\
\hline
\end{tabular}

a. Dependent Variable: $Y$

Pada Tabel 6 dikemukakan nilai koefisien dari persamaan regresi linier. Dalam penelitian ini menggunakan persamaan regresi linier sederhana yang diperoleh adalah $Y=35,240+1,120 \mathrm{X}$. Koefisien-koefisien regresi linier sederhana tersebut dapat diartikan koefisien regresi untuk konstan 35,240 merupakan konstan yang mempunyai arti bahwa jika tidak ada media diorama (X) maka nilai konsisten kemampuan berpikir tingkat tinggi $(Y)$ adalah sebesar 35,240. Dan variabel media diorama 1,120 menunjukan bahwa setiap penambahan $1 \%$ tingkat media diorama $(X)$, maka kemampuan berpikir tingkat tinggi $(Y)$ akan meningkat sebesar 1,120.

3. Hasil Uji Hipotesis (Uji t)

Setelah mengetahui besarnya koefisien regresi, maka perlu dilakukan pengujian hipotesis dengan menggunakan uji t untuk megetahui apakah terdapat pengaruh atau tidak. Hasil ujil $t$ dalam pengujian ini tercantum pada Tabel 7.

Tabel 7. Hasil uji hipotesis (uji t)

Coefficients $^{\mathrm{a}}$

\begin{tabular}{|c|c|c|c|c|c|c|}
\hline \multirow{2}{*}{\multicolumn{2}{|c|}{ Model }} & \multicolumn{2}{|c|}{ Unstandardized Coefficients } & \multirow{2}{*}{$\begin{array}{c}\text { Standardized } \\
\text { Coefficients } \\
\text { Beta }\end{array}$} & \multirow[b]{2}{*}{$t$} & \multirow[b]{2}{*}{ Sig. } \\
\hline & & $\mathrm{B}$ & Std. Error & & & \\
\hline & (Constant) & 35.240 & 22.874 & & 1.541 & .141 \\
\hline & $\mathrm{x}$ & 1.120 & .475 & .486 & 2.357 & .030 \\
\hline
\end{tabular}

a. Dependent Variable: $Y$

Pada Tabel 7 thitung pada media diorama adalah 2,357. Pada derajat bebas $(\mathrm{df})=\mathrm{N}-2=18$, maka ditemukan rtabel sebesar 0,468. Maka kesimpulannya adalah thitung $>t_{\text {tabel }}(2,357>0,468)$. Kriteria dalam kemampuan berpikir tingkat tinggi adalah sebagai berikut:

a. Jika thitung $>t_{\text {tabel }}$ maka $\mathrm{H}_{0}$ ditolak secara statistik adalah signifikan, dari hasil uji t nilai signifikan lebih kecil dari $0.05(0,000<0,05)$ berarti terdapat pengaruh yang erat media diorama terhadap kemampuan berpikir tingkat tinggi siswa kelas $\mathrm{V}$ pada pembelajaran matematika materi skala.

b. Jika thitung $<t_{\text {tabel }}$ maka $\mathrm{H}_{0}$ diterima, artinya secara statistik adalah tidak ada pengaruh yang signifikan antara media diorama terhadap kemampuan berpikir tingkat tinggi siswa kelas $\mathrm{V}$ pada pembelajaran matematika materi skala.

c. Berdasarkan kriteria a dan b maka $\mathrm{H}_{0}$ ditolak dan $\mathrm{H}_{\mathrm{a}}$ diterima. Berarti media diorama terhadap kemampuan berpikir tingkat tinggi siswa kelas $\mathrm{V}$ pada pembelajaran matematika materi skala di Ml Baitul Huda Klampisan.

Dari data tersebut maka dapat ditarik kesimpulan bahwasanya media diorama mempengaruhi kemampuan berpikir tingkat tinggi siswa kelas $\mathrm{V}$ pada pembelajaran matematika materi skala di Ml Baitul Huda. 


\section{Uji korelasi}

Langkah berikutnya untuk mendapatkan informasi pengaruh variable $X$ terhadap $Y$ maka melakukan analisis uji hipotesis yang diajukan. Analisis menggunakan korelasi product moment. Hasil rekapitulasi dapat dilihat dari Tabel 8.

Tabel 8. Hasil uji korelasi product moment

\begin{tabular}{llrr} 
& & \\
\hline & & $\begin{array}{c}\text { Penggunaan } \\
\text { Media Diorama }\end{array}$ & $\begin{array}{c}\text { Kemampuan Berpikir } \\
\text { Tingkat Tinggi }\end{array}$ \\
\hline Penggunaan Media Diorama & Pearson Correlation & 1 & $.486^{*}$ \\
& Sig. (2-tailed) & & .030 \\
& $N$ & 20 & 20 \\
Kemampuan Berpikir Tingkat Tinggi & $.486^{*}$ & 1 \\
& Pearson Correlation & .030 & 20 \\
& Sig. (2-tailed) & 20 & 20 \\
& N & &
\end{tabular}

*. Correlation is significant at the 0.05 level (2-tailed).

Dengan menggunakan perhitungan SPSS, telah berhasil diperoleh koefisien korelasi $\left(r_{x y}\right)$ sebesar 0,485. Jika diperhatikan angka 0,485 ini berarti menunjukkan adanya korelasi positif antara variabel $X$ dan variabel $Y$, karena tidak ada tanda negatif (-). Diketahui hasil dari $\Upsilon_{\text {hitung }}$ yaitu 0,485 yang berkisar antara 0,40-0,70, berdasarkan pedoman dapat kita nyatakan bahwa antara variabel $X$ dan variabel $Y$ itu mempunyai korelasi yang "Sedang atau Cukup". Dengan demikian simpulan yang dapat diambil bahwa korelasi antara media diorama (variabel $X$ ) dan kemampuan berpikir tingkat tinggi (variabel Y) merupakan korelasi yang "sedang atau cukup".

\section{KESIMPULAN}

Berdasarkan paparan data dan temuan peneltian di lapangan dapat disimpulkan: (1) Berdasarkan hasil angket peserta didik menunjukan rata-rata nilai 48 termasuk dalam kategori baik; (2) Berdasarkan hasil pretest dan posttest pada pembelajaran matematika materi skala diketahui perolehan rata-rata pretest yang semula sebesar 50,25 setelah diberikan posttest rata-rata kelas menjadi 89. Artinya kemampuan berpikir tingkat tinggi pada pembelajaran matematika materi skala peserta didik kelas $\mathrm{V}$ di MI Baitul Huda menggunakan media diorama dari kategori kurang menjadi baik; (3) Berdasarkan hasil uji korelasi, diperoleh koefisien korelasi sebesar 0,485 . Pada taraf signifikansi $5 \%$ didapat bahwa $r_{x y}$ dan $r_{0}$ adalah lebih besar dari $r_{\text {tabel }}(0,485>0,444)$ sehingga terdapat pengaruh signifikan media diorama terhadap kemampuan berpikir tingkat tinggi peserta didik kelas $\mathrm{V}$ pada pembelajaran matematika materi skala.

\section{REKOMENDASI}

Dengan memperhatikan hasil penelitian dan kesimpulan yang telah dikemukakan, peneliti menyarankan agar penelitian ini bisa dijadikan sebagai alternatif pembelajaran yang efektif dan dapat meningkatkan aktivitas serta pemahaman peserta didik terhadap materi matematika. Sehingga akan meningkatkan kualitas pendidikan matematika peserta didik.

\section{UCAPAN TERIMAKASIH}

Penulis mengucapkan terimakasih kepada Lembaga Pusat Kajian Pengembangan IImu Universitas Wahid Hasyim Semarang yang memberikan motivasi atas terselesaikannya riset ini. MI Baitul Huda Klampisan Semarang sebagai sekolah mitra.

\section{DAFTAR PUSTAKA}

Arifuddin, A., Alfiani, D. A., \& Hidayati, S. (2018). Pengaruh model pembelajaran inkuiri terhadap kemampuan pemecahan masalah matematika siswa kelas iv madrasah ibtidaiyah. Al Ibtida: 
Jurnal Pendidikan Guru MI, 5(2), 261-274.

Arikunto, S. (2006). Prosedur penelitian: Suatu pendekatan praktik. Jakarta: Rineka Cipta.

Creswell, J. W. (2009). Research design pendekatan kualitatif, kuantitatif, dan mixed (third). Yogyakarta: Pustaka Pelajar.

Fayakun, M., \& Joko, P. (2015). Efektivitas pembelajaran fisika menggunakan model kontekstual (CTL) dengan metode predict, observe, explain terhadap kemampuan berpikir tingkat tinggi. Jurnal Pendidikan Fisika Indonesia, 11(1), 49-58.

Lestari, A., Saepulrohman, A., \& Hamdu, G. (2017). Pengembangan soal tes berbasis hots pada model pembelajaran latihan penelitian di sekolah dasar. PEDADIDAKTIKA: Jurnal IImiah Pendidikan Guru Sekolah Dasar, 3(1), 74-83.

Lestari, S., \& Mulyani. (2015). Pengaruh penggunaan media diorama terhadap hasil belajar siswa kelas v pada tema ekosistem di sekolah dasar. Jurnal Penelitian Pendidikan Guru Sekolah Dasar, 3(2), 1114-1123.

Murdiyanto, T., \& Mahatama, Y. (2014). Pengembangan alat peraga matematika untuk meningkatkan minat dan motivasi belajar matematika siswa sekolah dasar. Jurnal Sarwahita, 11(1), 38-43.

Musyafa, Warsali, Milah, C. S., Aliyudin, Supianti, I. I., \& Amam, A. (2020). Pendekatan contextual teaching and learning (CTL) untuk meningkatkan pemahaman matematik siswa pada materi aritmatika sosial. Jurnal Teorema: Teori dan Riset Matematika, 5(1), 69-76.

Nurhayati, T., Alfiani, D. A., \& Setiani, D. (2019). The effect of crossword puzzle application on the students' learning motivation in science learning. Al Ibtida: Jurnal Pendidikan Guru MI, 6(1), 124-133.

Ratnaningsih, S., \& Nastiti, G. (2018). Upaya meningkatan motivasi belajar siswa dengan menggunakan media gambar pada pembelajaran tematik di sekolah dasar. Al Ibtida: Jurnal Pendidikan Guru MI, 5(2), 275-286.

Riadi, A., \& Retnawati, H. (2014). Pengembangan perangkat pembelajaran untuk meningkatkan hots pada kompetensi bangun ruang sisi datar. Pythagoras: Jurnal Pendidikan Matematika, 9(2), $126-135$.

Sari, L. N. I. (2017). Peningkatan kemampuan pemecahan masalah matematis siswa melalui pendekatan pendidikan matematika realistik. Logaritma: Jurnal IImu-IImu Pendidikan dan Sains, 5(1), 24-36.

Sari, M., Habibi, M., \& Putri, R. (2018). Pengaruh model pembelajaran kooperatif tipe think-pairs-share dalam pembelajaran matematika terhadap kemampuan pemahaman konsep matematis dan pengembangan karakter siswa sma kota sungai penuh. Edumatika: Jurnal Riset Pendidikan Matematika, 1(1), 7-21.

Sofiyah, S., Susanto, \& Setiawani, S. (2015). Pengembangan paket tes kemampuan berpikir tingkat tinggi matematika berdasarkan revisi taksonomi bloom pada siswa kelas $v$ sd (the development test package of higher order thinking skill of mathematics based on bloom's taxonomy revision for fifth grade. Artikel IImiah Mahasiswa, 1(1), 1-7. 
Sudijono, A. (2012). Pengantar statistika. Jakarta: Raja Grafindo Persada.

Sugiyono. (2015). Statistik untuk penelitian. Bandung: Alfabeta.

Sugiyono. (2016). Metode penelitian pendidikan pendekatan kuantitatif, kualitatif, dan R\&D. Bandung: Alfabeta.

Susanti, M., Zanthy, L. S., \& Fitriani, N. (2020). Deskripsi kesalahan siswa memecahkan soal berbentuk cerita pada materi segiempat. Teorema: Teori dan Riset Matematika, 5(1), 77-88.

Sutiarso, S., Coesamin, M., \& Nurhanurawati. (2018). The effect of various media scaffolding on increasing understanding of students' geometry concepts. Journal on Mathematics Education, 9(1), 95-102.

Zakiah, N. E. (2016). Meningkatkan kemampuan metakognitif siswa melalui pembelajaran dengan pendekatan open-ended. Teorema: Teori dan Riset Matematika, 1(1).

Zakiah, N. E., Sunaryo, Y., \& Amam, A. (2019). Implementasi pendekatan kontekstual pada model pembelajaran berbasis masalah berdasarkan langkah-langkah polya. Teorema: Teori dan Riset Matematika, 4(2), 111-120.

Zulfiani, Z., \& Suwarna, I. P. (2020). The effect of science adaptive assessment tool based on kolb learning style on high-level thinking skills. Edusains, 11(2), 310-319. 